\title{
Study on Nutrients, Mineral and Vitamin Profile of Moringa oleifera Leaf Meal
}

\author{
A. Ajantha, C. Kathirvelan*, M.R. Purushothaman and P. Visha \\ Veterinary College and Research Institute, Tamil Nadu Veterinary and Animal Sciences \\ University, Namakkal, 637002 Tamil Nadu, India \\ *Corresponding author
}

\section{A B S T R A C T}

\begin{tabular}{|l|}
\hline Ke y w o r d s \\
Moringa leaf meal, \\
Nutrient, Minerals, \\
Vitamins
\end{tabular}

The nutrient, minerals and vitamin analysis of Moringa oleifera leaf meal (MOLM) was analyzed in this study. Moringa leaves were harvested from different parts of Namakkal district of Tamilnadu. Stem and branches were cut from Moringa trees and spread out under the shade to dry at $35^{\circ} \mathrm{C}$ for seven days. The leaves were then removed manually, grounded into powder and preserved for use. The proximate analysis of sample for moisture, crude protein, crude fibre, ether extract, total ash was done as per the AOAC (1995). The nutrient composition of leaves recorded as; Moisture $(5.36 \%)$, crude protein $(26.01 \%)$, ether extract $(6.58 \%)$, crude fibre $(7.08 \%)$ and total ash $(9.41 \%)$. The mineral analysis revealed that high in Calcium (1.60\%), Potassium (1.38\%), Iron (285ppm), Zinc (38.02ppm), Copper (5.90ppm). The vitamin analysis revealed that vitamin $\mathrm{C}(17.31 \mathrm{mg})$ and vitamin $\mathrm{E}(113.70 \mathrm{mg})$ respectively. The result of nutrient, mineral and vitamin analysis of MOLM showed, MOLM can be used in the livestock and poultry diets with high protein and mineral value.

\section{Introduction}

The need to develop cheap and readily available alternative feeding material to support animal growth has become imperative. All parts of herbaceous plants as food by humans and animals, whole or in parts are generally considered as vegetables.

Vegetables include leaves, stems, roots, flowers, bulbs, seeds and fruits. Vegetables contain water soluble vitamins like vitamin B and vitamin $\mathrm{C}$, fat soluble vitamins including vitamin $\mathrm{A}$ and $\mathrm{D}$ and also contain a great variety of phytochemical constituents which have being claimed to have antioxidant, antibacterial, antifungal, antiviral and ant carcinogenic properties (Aja et al., 2013).

Moringa oleifera Lam. is a fast growing, drought - resistant tree and widely cultivated species of the Moringaceae family in tropical and subtropical countries. It is grown in India, Africa, South and Central America, Mexico, Hawaii, and throughout Asia and Southeast Asia. It has high biomass production of up to 2-4 ton/year/acre and height that ranges from 5 to $10 \mathrm{~m}$ (Fahey, 2005). It can survive in harsh climatic condition including destitute soil without being much affected by drought. It can tolerate wide range of rainfall requirements estimated at $250 \mathrm{~mm}$ and 
maximum at over $3000 \mathrm{~mm}$ and a $\mathrm{pH}$ of 5.0 to 9.0. Moringa oleifera is referred to as the 'drum stick tree' or the 'horse radish tree', whereas in others, it is known as the kelor, marango, mlonge, moonga, mulangay, saijhan, sajna or Ben oil tree (Anwar and Bhanger, 2003). Every part of the Moringa oleifera tree, from the roots to the leaves has beneficial properties. It is a multipurpose tree, various parts of which are used as fodder, herbal medicines, spices, food, natural coagulant, necter forbees, fuel and fertilizer.

It possesses important medicinal properties which include antibacterial and antifungal activities (Nickon et al., 2003) hepato protective (Pari and Kumar, 2002) and antioxidant, anti-inflammatory, anti-ulcer, anti tumor, hypocholesterimic activity. The leaves, flowers and pods are used as good sources of vitamins $\mathrm{A}, \mathrm{B}, \mathrm{C}$, and minerals $\mathrm{Ca}, \mathrm{K}, \mathrm{Mg}, \mathrm{Fe}$, $\mathrm{Zn}, \mathrm{Mn}, \mathrm{P}, \mathrm{Zn}, \mathrm{Na}, \mathrm{Cu}$, and $\mathrm{Fe}$.

The leaves are rich in carotene, iron and ascorbic acid. Moringa oleifera leaves have wide range of medicinal value including growth promotion and antimicrobial effect (Mbikay, 2012 and Moyo et al., 2011). Leaves of the Moringa tree are the preferred part for use in animal diets as leaf meal. Therefore the objective of the study was to determine the nutritional value of Moringa leaves would help to prepare data for feed supplements and alternative non- conventional feed ingredients for animals while the functional properties would assist in predicting the behaviour of nutrients in feed formulation.

\section{Materials and Methods}

\section{Collection and processing of Moringa oleifera leaves}

The Moringa oleifera leaves were randomly collected at ten places in Namakkal district of Tamil Nadu. The plant was authenticated at the Botanical survey of India, Coimbatore, and Tamil Nadu. Stem and branches were cut from Moringa trees and then leaves spread out under the shade to dry at $35^{\circ} \mathrm{C}$ for 7 days. The leaves were then removed manually, grounded into powder and preserved for experimental use.

\section{Proximate analysis of Moringa oleifera leaf meal (MOLM)}

The proximate analysis of Moringa oleifera leaf meal were moisture content, crude fibre, crude protein, Total ash and ether extract content were analysed by as per the standard method (AOAC, 1995).

\section{Mineral analysis of MOLM}

The mineral analysis of MOLM for calcium, phosphorous, Magnesium were analysed as per AOAC (1995). Sodium, potassium were determined by flame photometer while Atomic Absorption Spectrometer (AAS) was used to determine iron, zinc, copper (AOAC, 2005).

\section{Vitamin analysis of MOLM}

The B-complex and other water soluble vitamins determined included B1, B2, B3, and $\mathrm{C}$, Fat soluble vitamins analysed were vitamin

E (McMurray et al., 1980; Thompson and Duval, 1989).

\section{Results and Discussion}

The nutrients like moisture, crude protein, crude fibre, ether extract, total ash content in Moringa olifera leaf meal (MOLM) was given in the Table 1.

The samples contain considerable amount of crude protein $(26.01 \%)$ and ether extract $(6.58 \%)$, crude fibre $(7.08 \%)$, total ash $(9.41$ $\%)$ and moisture $(5.36 \%)$. 
Table.1 Nutrient composition of Moringa oleifera leaf meal (on DMB)

\begin{tabular}{|l|c|c|c|c|c|}
\hline \multicolumn{1}{|c|}{ Field } & Moisture (\%) & $\begin{array}{c}\text { Total ash } \\
(\%)\end{array}$ & $\begin{array}{c}\text { Crude Fibre } \\
(\%)\end{array}$ & $\begin{array}{c}\text { Crude Protein } \\
(\%)\end{array}$ & $\begin{array}{c}\text { Ether } \\
\text { Extract (\%) }\end{array}$ \\
\hline Ladhuvadi & 4.70 & 9.80 & 7.00 & 25.80 & 8.39 \\
\hline Mecheri & 5.10 & 9.20 & 6.50 & 26.50 & 5.20 \\
\hline Serapatty & 4.00 & 8.80 & 7.21 & 25.80 & 6.30 \\
\hline Elurpatty & 6.20 & 9.80 & 6.40 & 24.30 & 7.30 \\
\hline Mohanur & 4.20 & 10.10 & 7.50 & 26.30 & 6.80 \\
\hline Valaiyapatty & 8.00 & 7.90 & 7.82 & 25.40 & 5.10 \\
\hline Senthamangalam & 7.20 & 9.50 & 6.30 & 27.61 & 7.10 \\
\hline Kattupudhur & 4.20 & 8.60 & 8.20 & 26.20 & 8.60 \\
\hline Paramathiveelur & 4.60 & 10.20 & 6.80 & 25.90 & 5.30 \\
\hline Thuraiyur & 5.40 & 10.20 & 7.02 & 26.30 & 5.70 \\
\hline Average & $5.36 \pm 0.43$ & $9.41 \pm 0.24$ & $7.08 \pm 0.19$ & $26.01 \pm 0.26$ & $6.58 \pm 0.40$ \\
\hline Pooled sample & $7.00 \pm 0.26$ & $10.12 \pm 0.16$ & $6.51 \pm 0.30$ & $26.52 \pm 0.21$ & $6.81 \pm 0.18$ \\
\hline
\end{tabular}

Table.2 Mineral and Vitamin composition of Moringa olifera leaf meal (per $100 \mathrm{~g}$ of leaf meal)

\begin{tabular}{|l|c|}
\hline \multicolumn{1}{|c|}{ Nutrient } & Level \\
\hline Calcium (\%) & 1.60 \\
\hline Phosphorous (\%) & 0.28 \\
\hline Magnesium (\%) & 0.43 \\
\hline Sodium (\%) & 0.12 \\
\hline Potassium (\%) & 1.38 \\
\hline Iron (ppm) & 285 \\
\hline Zinc (ppm) & 38.02 \\
\hline Copper (ppm) & 5.90 \\
\hline Vitamin B1 (mg) & 2.64 \\
\hline Vitamin B2 (mg) & 20.50 \\
\hline Vitamin B3 (mg) & 8.20 \\
\hline Vitamin C (mg) & 17.31 \\
\hline Vitamin E (mg) & 113.70 \\
\hline Beta carotene (mg) & 16.32 \\
\hline
\end{tabular}

The mineral and vitamin composition of MOLM given the Table 2.

The mineral composition in the present study revealed that MOLM has good source of calcium, Potassium, Iron and Zinc. Similarly, good source of Vitamin C and E.
The average protein content in MOLM was 26.01 percent and similarly other authors expressed the crude protein value between 12.67 to 30.76 per cent (Lakshipriya et al., 2015). The high level of protein in MOLM revealed that MOLM can be used as protein source in livestock ration especially for poultry 
in the place of conventional protein ingredients.

The mineral and vitamin profile of MOLM in the present study shown that MOLM has rich in calcium, Zinc, Iron and Potassium. Similar observation also made by Zanu et al., (2012). Like minerals, MOLM rich in Vitamin C, E and beta carotene. Similar findings also reported by Lakshipriya et al., (2015) and Ali (2014).

The results of present study revealed that Moringa oleifera leaf meal contains an appreciable amount of crude protein, crude fibre and ether extract serving as a good source of protein for livestock and poultry. Similarly MOLM also contains high amount of calcium, potassium, iron, zinc and vitamin like vitamin $\mathrm{C}$ and E. It can be concluded thus Moringa oleifera leaf meal can contribute significantly to the nutrient requirement of livestock species.

\section{Acknowledgements}

The authors are grateful to the Dean, Veterinary College and Research Institute, Namakkal and Tamil Nadu Veterinary and Animal Sciences University, Chennai for providing the necessary facilities for carrying out this research work. This is part of M.V.Sc research work.

\section{References}

A.O.A.C., 1995. Official Methods of Analysis Association of Official Analytical Chemists, $16^{\text {th }}$ Edn, Washington, D.C, USA.

A.O.A.C., 2005. Association of Official Analytical Chemist Official Methods of Analysis. Association of Official Analytical Chemists 18th Ed. Gaithersburg USA, AOAC press: $1250-1255$.

Aja, P. M., Ibiam, U. A., Uraku, A. J., Orji, O. U., Offor,C. E. and Nwali, B. U. 2013.
Comparative Proximate and Mineral Composition of Moringa oleifera Leaf and Seed. Global. Adv. Res. J. Agri. Sci., 2(5): 137-141.

Ali, N., 2014. Moringa oleifera leaves possible uses as environmentally friendly material. Int J. Chm. Envt and Bio Sci., 2(2): 212-216.

Anwar, F. and Bhanger, MI. 2003 Analytical characterization of Moringa oleifera seed oil grown in temperate regions of Pakistan. $J$. Agric. Food Chem., 51: 6558-63.

Fahey, J., 2005. Moringa oleifera: A review of the medical evidence for its nutritional, therapeutic, and prophylactic properties, Trees Life J. 1:1-33.

Lakshmipriya, G., Kruthi, D. and Devarai, S.K. 2016. Moringa oleifera: A review on nutritive importance and its medicinal application. Food Sci., Human wellness. 5:49-56.

Mbikay, M., 2012. Therapeutic potential of Moringa oleifera leaves in chronic hyperglycemia and dyslipidemia. Pharmacol, 3: $1-2$.

Moyo, B., Masika, P.J., Hugo, A. and Muchenje, V. 2011. Nutritional characterization of Moringa (Moringa oleifera Lam) leaves. Afr. J. Biotechol, 10(60): 2925-2933.

Nickon, F., Saud, Z.A., Rehman, M.H. and Haque, M.E. 2003. In vitro antimicrobial activity of the compound isolated from chloroform extract of $M$. oleifera Lam. Pakistani Journal of Biological Sciences, 22: 1888-90.

Pari, L. and Kumar, N.A. 2002. Hepatoprotecive activity of Moringa oliefera on antitubercular drug induced liver damage in rats. Journal of Medicinal Food, 5: 171-177.

Zanu H.K., Asiedu, P., Tampuori, M., Abada, M. and Asante, I. 2012. Possibilities of using moringa (Moringa oleifera) leaf meal as a partial substitute for fishmeal in broiler chickens diets. Journal of Animal and Feed Research, 2: 70-75.

\section{How to cite this article:}

Ajantha, A., C. Kathirvelan, M.R. Purushothaman and Visha, P. 2018. Study on Nutrients, Mineral and Vitamin Profile of Moringa oleifera Leaf Meal. Int.J.Curr.Microbiol.App.Sci. 7(05): 24782481. doi: https://doi.org/10.20546/ijcmas.2018.705.284 